\title{
UPAYA PEMAKSIMALAN PROGRAM EKSTRAKULIKULER DALAM MEMINIMALISIR KECANDUAN GADGET PADA SISWA PASRAMAN DI KOTA BOGOR
}

\author{
Oleh : \\ I wayan Aditya Nugraha \\ Jurusan Pendidikan Agama Hindu \\ Sekolah Tinggi Agama Hindu Dharma Nusantara Jakarta \\ Email : $\underline{\text { iwayan666@gmail.com }}$
}

\begin{abstract}
This thesis is a discussion of efforts to maximize the extracurricular program in minimizing gadget addiction to pasaman students in the city of Bogor. The main subject of this thesis is a discussion about the procurement of extracurricular programs, types of activities, and the impact of extracurricular programs in minimizing gadget addiction. By way of interviewing informants, researchers get the data needed for writing this thesis. However, the researchers first conducted observations to look for data about gadget users and observations about extracurricular activities held by couples in the city of Bogor. From the results of observations obtained data that almost all students from grades seven to twelve have personal gadgets. The results of the study show that this extracurricular program affects and reduces the use of gadgets to pasaman students. It was proven from the statement of parents of students who saw changes in their children after participating in the extracurricular activities program.
\end{abstract}

Keyword : Extracurricular.Addiction, Gadget, Pasraman.

\section{Pendahuluan}

Perkembangan teknologi secara cepat telah membawa dunia memasuki era globalisasi yang serba maju dan modern. Pada zaman yang serba modern seperti ini, manusia dituntut mengikuti perkembangan zaman di mana kehidupan menjadi serba praktis, efektif, dan efisien. Hal ini dikarenakan oleh kebutuhan hidup yang semakin banyak dan kompleks. Oleh karena itu diciptakan alat-alat yang dapat membantu kelancaran dan meringankan beban pekerjaan manusia, salah satunya adalah gadget. Gadget adalah sebuah benda (benda atau barang elektronik) teknologi kecil yang memiliki fungsi khusus, tetapi sering diasosiasikan sebagai sebuah inovasi atau barang baru. Jenis gadget sangat beraneka ragam tergantung 
dari fungsinya, contohnya sepertihandphone, laptop, kamera digital, music player, (Mp3, Mp4, ipod), tablet, PSP (Play Station Portable), jam digital canggih dan lainlain. (Purnomo, 2014)

Teknologi saat ini mengalami perkembangan yang sangat pesat bukan hanya setiap bulan teknologi berkembang, akan tetapi setiap hari teknologi mengalami perkembangan. Perkembangan akan kebutuhan gadget saat ini sangatlah banyak dan beragam. Maka tak heran banyak orang berbondong-bondong untuk membeli gadget. Setiap harinya gadget dan perangkat lainnya habis terjual untuk digunakan oleh banyak user (pengguna). Pada era teknologi seperti saat ini, kebutuhan gadget adalah salah satu kebutuhan utama. Mulai dari anak sekolah, pengusaha dan lainnya memang sangat membutuhkan perangkat gadget, mulai dari smarthphone, komputer, laptop dan lainnya.

Semakin maju teknologi maka semakin banyak pula gadget yang akan digunakan. Apalagi sekarang semakin banyaknya aplikasi yang terus berkembang pesat. Maka tak heran bila semakin banyak orang yang ingin memiliki dan menggunakannya untuk kebutuhan dalam mencari dan mendapatkan informasi yang dibutuhkan setiap harinya. Gadget memang salah satu hal yang mampu mempercepat menyelesaikan berbagai macam tugas dan pekerjaan sehingga gadget menjadi salah satu alat untuk menyelesaikan berbagai macam tugas dan pekerjaan. Sehingga dunia ini penuh dengan peralatan gadget yang menjadi kebutuhan utama dalam dunia internet atau dunia informasi komunikasi dan teknologi terbaru saat ini.Selain untuk membantu memudahkan kegiatan manusia gadget juga menjadi menjadi gaya hidup masyarakat modern. Salah satu gadget yang hampir setiap orang setiap orang memilikinnya adalah handphone. Karena handphone adalah salah satu gadget berkemampuan tinggi yang ditemukan dan diterima secara luas oleh berbagai negara di belahan dunia. (Sari, 2016)

Namun pada saat ini, gadget tidak hanya dapat digunakan oleh kalangan yang membutuhkan alat ini saja tapi juga hampir kalangan remaja dan anak-anak sudah memanfaatkan gadget dalam aktifitas yang mereka lakukan setiap hari. Adapun dampak positif yang ditimbulkan dari adanya gadget ini seperti mudahnya mencari konten anak-anak yang tidak ada dalam tayangan televisi namun terdapat 
dalam media-media yang tersedia dalam gadget tersebut, lalu memudahkan komunikasi orangtua dengan anak-anaknya, dan masih banyak manfaat dari kehadiran gadget ini dalam kehidupan sehari-hari. Gadget dapat diibaratkan piasu yang bermata dua, bagaimana disatu sisi gadget memiliki manfaat yang sangat berguna untuk kehidupan manusia dan sarana pembelajaran baru selain buku, namun dilain sisi dapat dikatakan bahwa gadget justru yang merajai kehidupan seseorang atau dapat disebut dengan kecanduan. Situasi dimana seseorang tidak dapat lepas dari hal yang disebut gadget dalam kehidupannya. Hal ini sungguh sangat memprihatikan dan sudah banyak terjadi, seseorang tidak dapat lepas dari gadgetnya. (Purnomo, 2014)

Berangkat dari masalah gadget tersebut, Sekolah adalah tempat yang tepat untuk meminimalisir pemakaian gadget, dengan salah satunya adalah Pendidikan. Pendidikan merupakan satu aspek penting dalam kehidupan manusia. Melalui proses sumber daya manusia yang ada dirubah dari yang ridak tahu menjadi tahu dan mampu membawa hasil berupa perubahan yang lebih baik. Proses pendidikan ini senatiasa diharapkan dapat mencapai keberhasilan baik dalam bidang ilmu pengetahuan maupun menerapkan nilai-nilai etika sebagai hasil proses pendidikan budi pekerti. Pendidikan merupakan usaha sadar yang dilakukan oleh pendidik yang mempunyai tujuan untuk mempersiapkan peserta didik dalam belajar melaui suatu aktifitas pengajaran, tuntunan serta latihan untuk peranannya dimasa yang akan datang. (Arikunto, 1993)

Pendidikan adalah investasi jangka panjang yang membutuhkan usaha dan danayang cukup besar, hal ini diakui oleh semua orang atau suatu bangsa demi kelangsungan masa depannya. Demikian halnya dengan Bangsa Indonesia menaruh harapan besar terhadap guru dan peserta didik dalam perkembangan masa depan bangsa ini, karena dari sanalah tunas muda harapan bangsa sebagai generasi penerus dibentuk.Implikasi lebih jauh dari kondisi ini menjadikan peserta didikkurang memperhatikan karakteristik dirinya.Titik tekan pendidikan hanya pada aspek kognitif, seperti yang selama ini dikembangkan,dalam kenyataannya menyisakan berbagai macam persoalan. Kualitas peserta didikdari tahun ke tahun justru semakin terpuruk, melihat kondisi seperti ini guru hendaknya mengubah 
paradigma pemikirannya bahwa peserta didikitu memiliki corak dan karakteristik yang satu sama lain berbeda. Agar keperluan seluruh peserta didik terpenuhi dan perkembangan kapabilitas peserta didik semakin meningkat.

Undang Undang No. 20 tahun 2003 tentang Sistem Pendidikan Nasional Pasal 3 mengamanatkan bahwa:

"Pendidikan nasional berfungsi mengembangkan kemampuan dan membentuk watak serta peradaban bangsa yang bermartabat dalam rangka mencerdaskan kehidupan bangsa, bertujuan untuk berkembangnya potensi peserta didik agar menjadi manusia yang beriman dan bertakwa kepada Tuhan Yang Maha Esa, berakhlak mulia, sehat, berilmu, cakap, kreatif, mandiri, dan menjadi warga negara yang demokratis serta bertanggung jawab". (Nasional, 2010)

Karakter dan Kreativitas dalam berfikir peserta didik tercermin dalam berbagai hal, diantaranya dalam diri peserta didik pun punya hasrat untuk selalu ingin tahu, tidak langsung menerima begitu saja apa yang disampaikan guru. Peserta didik selalu mengajukan berbagai pertanyaan berkaitan dengan materi yang disampaikan, apabila merasa kurang puas dengan penjelasan guru, mereka mencari referensi sendiri baik dari buku-buku ataupun internet. Keberhasilan belajar yang baik akan mempengaruhi keterlibatan peserta didik untuk aktif dalam pembelajaran sehingga tercapai hasil belajar yang optimal.

\section{RUMUSAN MASALAH}

Berdasarkan latar belakang yang ada diatas, maka permasalahan yang diangkat dalam penelitian ini adalah :

1.2.1 Apa sajakah kegiatan ekstrakulikuler di Pasraman dan apa yang melatar belakangi dilakukannya kegiatan ekstrakulikuler tersebut?

1.2.2 Apakah kegiatan ekstrakulikuler di pasraman Kota Bogor sudah berjalan dengan baik dan dapat meminimalisir kecanduan siswa pada Gadget?

\section{Tujuan Penelitian}

Seperti yang telah diketahui bahwa sesuatu yang sudah direncanakan tentu memiliki maksud dan tujuan yang dicapai. Demikian pula dalam hal karya ilmiah 
yang sengaja disusun penulis dalam tulisan ini dengan maksud tertentu dengan harapan dapat tercapainya harapan dan rencana yang telah dirancang. Maka dari itu, tujuan Penelitian yang ingin dicapai adalah :

1. Untuk mengetahui berbagai kegiatan ekstrakulikuler dan latar belakang dilakukannya kegiatan ekstrakulikuler di Pasraman kota Bogor.

2. Untuk mengetahui apakah kegiatan ekstrakulikuler di Pasraman Kota Bogor sudah berjalan dengan baik dan dapat mengurangi kecanduan siswa pada gadget.

Adapun manfaat dalam penelitian ini, peneliti berharap agar dapat memberikan sebuah sumbangan ilmu pengetahuan tambahan berupa karya ilmiah yang sangat berharga dalam perkembangan ilmu pendidikan dan juga memberi suatu pedoman untuk meminimalisir masalah yang ditimbulkan dari gadget pada peserta didik dengan menggunakan program ekstrakulikuler.

\section{Metodologi Penelitian}

Penelitian ini menggunakan metode kualitatif, dengan menggunakan analisa deskriptif kualitatif (Sugiyono, 2011) . Pengumpulan data yang digunakan dengan menggunakan wawancara. Penentuan informan yang dilakukan dalam penelitian ini adalah dengan menggunakan metode Purposive Sampling atau ditentukan berdasarkan tujuan dan kepentingan dari data yang diharapkan oleh penulis. Kemudian informan ini berkembang dalam bentuk Snowballing Sampling yaitu dengan cara menentukan informan semula yang jumlahnya sedikit kemudian bertambah dan mendapatkan data yang lengkap baru kemudian diakhiri.

Dalam penelitian kualitatif yang beraliran fenomenologis lebih menitikberatkan pada kenyataan yang bersifat global, sehingga walaupun lokasinya terbatas, responden sedikit akan tetapi jika data tersebut merupakan kenyataan yang berlaku, maka data tersebut sudah cukup membuktikan kebenaran.(Cholid, 2003)

Selanjutnya dalam menganalisa hasil penelitian ini penulis melakukan serangkaian tentang mengkodefikasi data yang telah dikumpulkan dan mengkombinasinya dengan data yang sudah ada baik itu data primer ataupun data 
sekunder. Berdasarkan uraian tersebut di atas penyajian data yang dilakukan dalam bentuk diskriptif yaitu data diuraikan dalam kalimat-kalimat sehingga membentuk suatu pengertian yang berhubungan dengan masalah yang diteliti.(Darmadi, 2014)

\section{Hasil dan Pembahasan}

\section{Kegiatan Ekstrakulikuler di Pasraman Kota Bogor dan Latar Belakang Pengadaan Kegiatan Ekstrakulikuler}

Setiap lembaga pendidikan pasti akan mempunyai program yang sudah tersusun sedemikian rupa untuk keberhasilan mencapai tujuan pembelajaran. Sesuai dengan UU No. 20 Tahun 2003, pengertian pendidikan adalah usaha sadar dan terencana untuk mewujudkan suasana belajar dan proses pembelajaran agar pesertadidik secara aktif mengembangkan potensi dirinya untuk memiliki kekuatan spritual keagamaan, pengendalian diri, kepribadian, kecerdasan, akhlak mulia, serta keterampilan yang diperlukan dirinya, masyarakat, bangsa, dan negara. Wilayah pendidikan yang akan membawa hal yang positif bagi siswa-siswanya, maka banyak kegiatan yang dirancang pihak sekolah untuk mengarahkan peserta didik kearah yang positif sesuai dengan minat dan bakat dari peserta didik tersebut. Sejalan dengan hal tersebut, pasraman yang juga termasuk dalam lembaga pendidikan juga memiliki rancangan-rancangan kegiatan yang diharapkn dapat mengarahkan peserta didik kearah yang positif. Salah satu program pasraman yang disamakan dengan sekolah umum adalah program kegiatan ekstrakulikuler. (Nasional, 2010)

Kegiatan ekstrakulikuler merupakan kegiatan yang dianjurkan dalam Undang Undang No. 20 tahun 2003 tentang Sistem Pendidikan Nasional Pasal 3 mengamanatkan bahwa:

"Pendidikan nasional berfungsi mengembangkan kemampuan dan membentuk watak serta peradaban bangsa yang bermartabat dalam rangka mencerdaskan kehidupan bangsa, bertujuan untuk berkembangnya potensi peserta didik agar menjadi manusia yang beriman dan bertakwa kepada Tuhan Yang Maha Esa, berakhlak mulia, sehat, berilmu, cakap, kreatif, mandiri, dan menjadi warga negara yang demokratis serta bertanggung jawab"(Nasional, 2010) 
Bagaimana sebuah aturan yang mengamanati lembaga-lembaga pendidikan tentang pengembangan kemampuan peserta didik, oleh karena itu program kegiatan ektrakulikuler dapat dikatakan sebagai program pengembangan diri. Disebut demikian karena memang tujuan dari program tessebut adalah mengembangkan kemampuan yang terdapat pada setiap peserta didik. (Bugin, 2011)

\section{Kegiatan Ekstrakulikuler Di Pasraman Kota Bogor}

Pencapaian tujuan pendidikan secara optimaltidak hanya dapat tercapai melaluitatap muka di dalam kelas, sebab proses belajar mengajar dalamkelas hanya bersifat pengembangan aspek kognitif siswa sehingga cenderung mengabaikan aspek lainnya (afektif dan psikomotorik). Pengembangan aspek afektif dan psikomotorik, akan lebih mudah dicapai melalui bentuk penghayatan dan pengalaman secara langsung. Dalam arti bahwa bentuk pengajaran tidak hanya dapat dicapai dalam bentuk tatap muka dalam kelas melainkan juga harus ditunjang melalui bentuk pengajaran di luar jadwal jam pelajaran di kelas, seperti kegiatan ekstrakurikuler.

Untuk mendefinisikan pengertian kegiatan ekstrakurikuler akan dikemukakan beberapa pendapat yaitu :

Ambo Elo adam dan Ismail Tolla mengemukakan:kegiatan ekstrakurikuler adalah kegiatan kurikuler yang berlaku di sekolah sebagai penunjang pendidikan formal (yang berlangsung di dalam sekolah).

Kegiatan ekstrakurikuler merupakan bentuk kegiatan di luar program kurikulum sekolah, yang diberikan kepada siswa sebagai penunjang pendidikan formal dan dimaksudkan sebagai bentuk pengembangan salah satu bidang pelajaran yang diminati oleh siswa, seperti olahraga, kesenian, keagamaan, dan lain sebagainya.Kegiatan ekstrakurikuler mempunyai relevansi yang tinggi terhadap program pendidikan formal lainnya. Hal tersebut dapat diidentifikasi dari bentuk kegiatan siswa di luar jadwal jam pelajaran sekolah, seperti dalam kegiatan Palang Merah Remaja yang efektif mengembangkansemangat kebersamaaan rasa solidaritas terhadap sesama insan dan lain sebagainya. (elo, ambo dan tolla, 1987)

\section{Program Ekstrakulikuler dan Orang Tua}

Kegiatan ekstrakulikuler merupakan bentuk kegiatan di luar program kurikulum sekolah, yang diberikan kepada siswa sebagai penunjang pendidikan 
formal yang dimaksudkan sebagai bentuk pengembangan salah satu bidang pelajaran yang diminati oleh siswa, seperti olahraga, kesenian, keagamaan, dan lain sebagainya. Mengenai tujuan program ekstrakulikuler dijelaskan dalam Departemen Pendidikan dan Kebudayaan. Lalu Visi dan misi kegiatan ekstrakurikuler menurut Rohinah, M. Noor, sebagai berikut :

1) Visi

Visi kegiatan ekstrakurikuler adalah berkembangnya potensi, bakat, dan minat secara optimal, serta tumbuhnya kemandirian dan kebahagiaan peserta didik yang berguna untuk diri sendiri, keluarga, dan masyarakat.

2) Misi

a. Menyediakan sejumlah kegiatan yang dapat dipilih oleh peserta didik sesuai dengan kebutuhan, potensi, bakat, dan minat mereka.

b. Menyelenggarakan kegiatan yang memberikan kesempatan peserta didik mengekspresikan diri secara bebas melalui kegiatan mandiri atau kelompok. (M.Noor, 2012)

\section{Gadget Pada Keseharian Siswa Di Rumah Dan Kecanduan Gadget Pada Siswa}

Seperti pendapat dari Sari dan Mitsalia (2016) dalam mengemukakan tentang intensitas penggunaan gadget dikategorikan dengan intensitas tinggi jika menggunakan gadget dengan durasi lebih dari 120 menit /hari dan dalam sekali pemakaiannya berkisar $>75$ menit. Selain itu, dalam sehari bisa berkali-kali (lebih dari 3 kali pemakaian) pemakaian gadget dengan durasi $30-75$ menit akan menimbulkan kecanduan dalam pemakaian gadget. Selanjutnya, penggunaan gadget dengan intensitas sedang jika menggunakan gadget dengan durasi lebih dari 40-60 menit/hari dan intensitas penggunaanan dalam sekali penggunaan 2-3 kali/hari setiap penggunaan. Kemudian, penggunaan gadget yang baik adalah dengan kategori rendah yaitu dengan durasi penggunaan kurang dari 30 menit /hari dan intensitas penggunaan maksimal 2 kali pemakaian. Durasi yang lama dalam penggunaan gadget ini yang dapat dikatakan seseorang sudah kecanduan terhadap gadget. Hal ini dapat menimbulkan yang negatif apabila tidak mengambil tindakan yang tepat. Pertama yang harus dilakukan orang tua adalah mengawasi apa saja yang dilakukan dan diakses anak dalam menggunakan gadget. Dapat diketahui 
bahwa dalam jejaring internet terdapat berbagai konten, baik dari yang positif sampai dengan yang negatif dapat diakses dengan mudahnya. Namun ada pendapat lain yang mengemukakan anaknya bisa menggunakan gadget sampai dengan enam jam, akan tetapi menurut peneliti bukan termasuk dalam kecanduan gadget pada umumnya. Hal ini bagaimana orang tua yang dapat tegas dalam mengatur penggunaan gadget, bagaimana membuat kesepakatan dalam menggunakan gadget tersebut. Hal ini sangat menarik, karena bagaimanapun memang peran pengawasan orang tua itu sangatlah penting.(Sari, 2016)

Pengawasan orang tua terhadap pengunaan gadget pada anak juga sangatlah penting, seperti yang diketahui bahwa gadget adalah sebuah barang yang diibaratkan pisau yang bermata dua. Dapat menjadi barang yang positif, tapi dapat juga menjadi barang yang negatif. Untuk orang yang sudah mengerti akan hal ini mungkin akan memanajemen dirinya agar gadget dapat bermanfaat bagi dirinya. Namun, bagaimana jika anak-anak yang belum terlalu mengerti dalam hal memanajemen dirinya untuk menjadikan gadget menjadi barang yang bermanfaat. Oleh karena itu pengawasan orang tua yang akan mengarahkan diri anak tersebut untuk menggunakan barang tersebut menjadi suatu barang yang bermanfaat.

\section{Dampak Kegiatan Ekstrakulikuler Dalam Meminimalisir Kecanduan Pada Gadget Siswa Pasraman Kota Bogor}

Sebuah kegiatan dirancang sedemikian rupa untuk memiliki dampak yang akan dirasakan oleh orang yang melakukan kegiatan tersebut. Begitu pula kegiatan ekstrakulikuler yang mempunyai tujuan, visi, dan misi untuk sesuatu yang ingin dicapi oleh kegiatan yang sudah diprogramkan dalam kurikulum. Bagaimana dampak yang diharapkan muncul setelah siswa mengikuti kegiatan tersebut adalah dampak positif yang mengubah sikap dan minat seorang siswa setelah berpastisipasi dan mendalami kegiatan tersebut. Hal ini secara tidak langsung juga termasuk dalam tujuan dari kegiatan ekstrakulikuler, dimana kegiatan ekstrakulikuler selain bertujuan untuk memberikan wadah bagi siswa untuk mengembangkan bakat dan minat para siswa, kegiatan ekstrakulikuler juga akan memberikan sebuah kegiatan tambahan yang menyibukan siswa. Dengan sibuknya siswa, hal ini akan meminimalisir penggunaan gadget dalam bentuk apapun. (Fadlilah, 2015) 


\section{Kesimpulan}

Berdasarkan hasil penelitian diatas yang dilakukan oleh peneliti tentang Upaya Pemaksimalan Program Ekstrakulikuler Dalam Meminimalisir Kecanduan Gadget Pada Siswa Pasraman Di Kota Bogor, maka dapat ditarik kesimpulan seperti berikut

1. Rumusan Masalah Pertama :

a. Kegiatan ekstrakulikuler merupakan kegiatan tambahan yang diadakan pada jam setelah selesainya jam mata pelajaran. Pada Pasraman di Kota Bogor, kegiatan ini ada berdasarkan pada peraturan yang berlaku dan mengatur tentang kegiatan ekstrakulikuler.

b. Ada banyak jenis kegiatan yang disediakan oleh pihak pasraman untuk siswa sesuai dengan minat dan bakat siswa untuk mengikuti kegiatan ekstrakulikuler.

c. Partisipasi dan antusiasme siswa dalam mengikuti kegiatan dapat dikatakan sangat baik. Dengan setiap minggu pelaksanaan kegiatan ini siswa selalu bersemangat dalam mengikuti kegiatan ekstrakulikuler.

d. Kegiatan ekstrakulikuler yang ada di Kota bogor sudah dapat dikatakan berjalan dengan baik, dan berjalan secara structural.

2. Rumusan Masalah Kedua :

a. Kegiatan ekstrakulikuler juga membawa dampak yang baik bagi para siswa, baik perubahan pada sikap, perilaku, maupun meminimalisir tingkat kecanduan siswa terhadap gadget.

b. Pengetahuan orang tua terhadap kegiatan ekstrakulikuler yang sudah baik, para orang tua mengetahui dan paham manfaat dari kegiatan ekstrakulikuler.

c. Orang tua mendukung adanya kegiatan ekstrakulikuler karena dampak positif yang diperlihatkan oleh anaknya setelah mengikuti kegiatan ekstrakulikuler.

\section{Daftar Pustaka}

Arikunto, S. (1993). Dasar-dasar Evaluasi Pendidikan. Yogyakarta: Bumi Aksara. 
Bugin, B. (2011). Penelitian Kualitatif (Komunikasi, Ekonomi, Kebijakan Publik, dan Ilmu Sosial Lainnya). Jakarta: Kencana.

Cholid, N. (2003). Metodologi Penelitian. Jakarta: Bumi Aksara.

Darmadi, H. (2014). Metode Penelitian Pendidikan dan Sosial. Bandung: Alfabeta.

Fadlilah, N. (2015). Gadget Dan Generasi Muda. Bandung. Bandung: Alfabeta.

Hurlock, B. (1993). Psikologi Perkembangan (5th ed.). Jakarta: Erlangga.

elo, ambo dan tolla, I. (1987). Dasar-dasar Administrasi Pendidikan. Padang.

M.Noor, R. (2012). Membangun Karakter Melalui Kegiatan Ekstrakurikuler. Yogyakarta: Insan Madani.

Nasional, K. P. (2010). Himpunan Undang-Undang dan Peraturan Pemerintah Bidang Pendidikan. Jakarta.

Sari, P. (2016). Pengaruh Penggunaan Gadget Terhadap Personal Sosial Anak Usia Pra Sekolah di Tkit Al Mukmin. Jurnal Profesi.

Sugiyono. (2011). Metode Penelitian Pendidikan (Pendekatan Kuantitatif, Kualitatif dan Research and Development) (12th ed.). Bandung: Alfabeta.

Suryosubroto. (1993). Proses Pembelajaran di Sekolah. Jakarta: Rineka Cipta.

Ramadhan, A. (2017). Hubungan Tingkat Kecanduan Gadget Dengan Gangguan Emosi dan Perilaku Remaja Usia 11-12 Tahun. Jurnal Kedokteran Umun.

Purnomo, A. (2014). Hubungan Antara Kecanduan Gadget (Mobile Phone)

Dengan Empati Pada Mahasiswa. Yogyakarta. 